\title{
Tracer Study Terhadap Respon Stakeholder untuk Evaluasi dan Pengembangan Kurikulum Program Studi
}

\author{
Resi Pratiwi, Atik Rahmawati \\ UIN Walisongo Semarang \\ *Correspondence adress: pratiwiresi@walisongo.ac.id

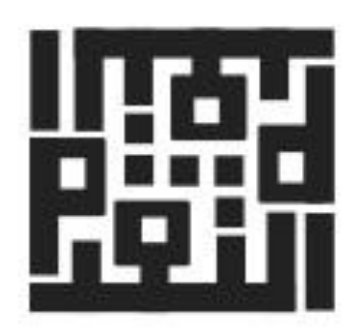 \\ ISSN: 1979-4703 (p) \\ ISSN: 2527-9726 (e) \\ Keywords:

\section{A B S T RA C T} \\ This study aimed to determine the graduate user assessment (stakeholder \\ response). The method used is through a preliminary survey phase of the alumni \\ database, creating a google form tracer study of stakeholder responses, tracking \\ stakeholder responses, distributing tracer study questionnaires and random \\ stakeholder interviews. The research sample is the 2012-2014 class of \\ chemistry graduate users who have been recorded in a tracer study of aspects of \\ alumni tracking. The results of the study show that the assessment of graduates \\ according to stakeholders is integrity (moral and ethics) very good category \\ (63\%), professionalism is good (51\%), information technology is good (61\%), \\ teamwork is good (aspects) 63\%), good personal development aspects (63\%), \\ good leadership aspects (80\%), good foreign language skills (68\%), good \\ communication skills (73\%), innovation ability and creativity good category \\ (59\%), and motivation in working good category (51\%).
}

Tracer Study, Respon

Stakeholder, Pengguna

lulusan

\section{A B S T R A K}

Penelitian ini ditujukan untuk mengetahui penilaian pengguna lulusan (respon stakeholder). Metode yang digunakan yaitu melalui tahap survey pendahuluan terhadap database alumni, pembuatan google form tracer study respon stakeholder, melakukan penelusuran respon stakeholder, penyebaran kuesioner tracer study serta wawancara terhadap stakeholder yang dilakukan secara acak. Sampel penelitian adalah pengguna lulusan pendidikan kimia angkatan tahun 2012-2014 yang sudah terdata pada tracer study penelusuran aspek alumni. Hasil penelitian menunjukkan penilaian lulusan menurut stakeholder yaitu aspek integritas (moral dan etika) kategori sangat baik (63\%), aspek profesionalisme kategori baik (51\%), aspek penguasaan teknologi informasi kategori baik (61\%), aspek kerjasama dalam tim kategori baik (63\%), aspek pengembangan diri kategori baik (63\%), aspek kepemimpinan kategori baik (80\%), aspek kemampuan berbahasa asing kategori baik (68\%), aspek kemampuan berkomunikasi kategori baik (73\%), aspek kemampuan inovasi dan aspek kreativitas kategori baik (59\%), dan motivasi dalam bekerja kategori baik (51\%). 


\section{Pendahuluan}

Berdasarkan Undang-Undang Nomor 12 tahun 2012, pendidikan tinggi adalah jenjang pendidikan setelah pendidikan menengah yang mencakup program diploma, program sarjana, program magister, program doktor, dan program profesi, serta program spesialis, yang diselenggarakan oleh perguruan tinggi berdasarkan kebudayaan bangsa Indonesia. Salah satu tujuan perguruan tinggi yaitu menghasilkan lulusan yang menguasai cabang ilmu pengetahuan dan/atau teknologi untuk memenuhi kepentingan nasional dan peningkatan daya saing bangsa sehingga kesesuian bidang pengetahuan dan pekejaan diperlukan. Selain itu, pengelola institusi pendidikan di samping menekankan keseimbangan muatan intelektual, emosional, maupun spiritual dalam desain kurikulum yang dimilikinya, juga sebisa mungkin harus mengakomodasi keperluan dari dunia kerja. Hal tersebut dikarenakan proses perubahan dan perkembangan yang dinamis selalu terjadi di dunia kerja. Kondisi semacam itu kemudian juga berdampak pada dinamisnya kebutuhan pasar akan kualifikasi tenaga kerja yang diinginkan. Oleh karenanya, untuk selalu bisa mengikuti perkembangan dengan permintaan dunia kerja, maka pengelola institusi pendidikan seperti perguruan tinggi harus senantiasa memperhatikan dan mengakomodasi kebutuhan dari dunia kerja.

Jurusan Pendidikan Kimia Fakultas Sains dan Teknologi Universitas Islam Negeri Walisongo Semarang merupakan salah satu jurusan yang memiliki visi untuk unggul dan kompetitif berwawasan Education for Sustainable Development melalui riset berbasis Kesatuan Ilmu Pengetahuan di tingkat Asia pada Tahun 2038. Misi yang diemban adalah : (1) menyelenggarakan pendidikan kimia berwawasan Education for Sustainable Development berbasis kesatuan ilmu pengetahuan dan kearifan lokal; (2) mengembangkan pendidikan kimia melalui Riset berwawasan Education for Sustainable Development berbasis kesatuan ilmu pengetahuan dan kearifan lokal serta menyebarluaskan hasil riset pada skala nasional maupun internasional; (3) menyelenggarakan pengabdian kepada masyarakat sebagai implementasi hasil Riset berwawasan Education for Sustainable Development berbasis kesatuan ilmu pengetahuan dan kearifan lokal; (4) Melakukan kerjasama dengan pihak-pihak terkait di tingkat regional, nasional, dan internasional; (5) menyelenggarakan tata kelola Program Studi Pendidikan Kimia yang efektif, efisien, dan transparan.

Dalam rangka mewujudkan visi dan misi tersebut diperlukan keterlibatan alumni/lulusan dan pengguna lulusan (stakeholder). Umpan balik yang diberikan alumni dan stakeholder, pada umumnya dapat bermanfaat dalam membantu perguruan tinggi untuk perbaikan sistem dan pengelolaan pendidikan. Salah satu metode yang dapat digunakan untuk membantu perguruan tinggi untuk mendapatkan umpan balik dari alumni dan stakeholder dalam rangka perbaikan sistem dan pengelolaan pendidikan adalah dengan melaksanakan Tracer study.

Permendikbud No.5 Tahun 2020 menyebutkan bahwa peringkat akreditasi yang telah diberikan dapat ditinjau kembali oleh BAN-PT sebelum jangka waktu Akreditasi berakhir apabila terdapat penurunan mutu dalam hal: 
a. menurunnya jumlah peminat/pendaftar dan/atau lulusan pada Program Studi yang ada selama 5 (lima) tahun berturut-turut berdasarkan data pada PDDikti; dan/atau

b. terdapat laporan pengaduan Masyarakat atas dugaan pelanggaran penyelenggaraan pendidikan tinggi sesuai dengan ketentuan peraturan perundang-undangan.

c. Informasi yang berkaitan dengan mutu alumni dapat dilakukan dengan melakukan tracer study. Tracer study dapat dilakukan setiap tahun, agar prodi dapat mengetahui bagaimana kualitas lulusan dan respon pengguna lulusan.

Tracer study atau yang sering disebut sebagai survey alumni atau survey "follow up" adalah studi mengenai lulusan lembaga penyelenggara pendidikan tinggi. Studi ini mampu menyediakan berbagai informasi yang bermanfaat bagi kepentingan evaluasi hasil pendidikan tinggi yang selanjutnya dapat digunakan untuk penyempurnaan dan penjaminan kualitas lembaga pendidikan tinggi yang bersangkutan (Schomburg, 2011). Tracer study merupakan studi yang dilakukan terhadap lulusan perguruan tinggi maupun pengguna lulusan yang terkait dengan transisi perguruan tinggi dan dunia kerja.

Toba, et al. (2017) menyatakan bahwa database alumni merupakan sumber informasi yang sangat berharga bagi pengembangan universitas. Pannogan \& Ocampo (2016) juga menyatakan hal yang kurang lebih sama, bahwa penelusuran alumni merupakan aktivitas yang bermanfaat diantaranya untuk peningkatan kualitas pembelajaran, menangkap pasar (permintaan, kepuasan), dan membangun jejaring alumni. Nugroho (2018) menyatakan bahwa profil mahasiswa dan lulusan adalah salah satu data yang sangat dibutuhkan suatu universitas dalam proses akreditasi.

Beberapa peneliti telah mengembangkan aplikasi untuk dapat mengungkap profil lulusan. Wibisono, et al. (2012) mengembangkan Integrated Tracer study System (ITSS) untuk dapat meningkatkan kualitas data yang diperoleh dalam penelusuran alumni. Sistem ini dapat digunakan untuk memperoleh data alumni yang cukup luas dalam waktu yang relatif terbatas. Khair, et al (2016) mengembangkan sistem penelusuran alumni berbasis web. Aplikasi yang digunakan yaitu PHP dan MySQL database. Sistem tersebut dapat merekam data dengan baik melalui website secara online sehingga kegiatan penelusuran alumni dapat dilakukan dengan efektif dan efisien. Nugroho (2018) berhasil mengembangkan aplikasi OLAP untuk menampilkan prosentase IPK lulusan berdasarkan range tertentu dan menampilkan IPK minimum, rata-rata dan maksimum.

Tracer study terhadap alumni jurusan Pendidikan Kimia UIN Walisongo Semarang sebenarnya sudah dilakukan oleh Minhayati pada tahun 2010 dan dilanjutkan kembali oleh Rahmawati tahun 2012. Namun saat itu tidak ada pengklasifikasian khusus alumni perangkatan. Sehingga kesimpulan yang di peroleh tidak begitu relevan dengan kondisi saat ini. Seiring berjalannya waktu juga pendidikan kimia mengalami perkembangan yang pesat. Sehingga perlu penelusuran alumni kembali untuk memperoleh indikator yang jelas tentang jumlah, profil kerja masa mendatang serta pelatihan yang diperlukan.

Penelitian ini ditujukan untuk mengetahui penilaian pengguna lulusan (respon stakeholder). Tracer study berbasis online (google form) digunakan untuk memudahkan pengisian dan pemetaan hasil penilaian. Indikator penilaian dari stakeholder yang digunakan, disesuaikan dengan kebutuhan jurusan dalam rangka perbaikan kurikulum. Selain itu, aspek 


\section{At-Taqaddum}

Vol. 12 No. 1 (2020) 55-74

penilaian lulusan oleh stakeholder sebagai pengguna lulusan berdasarkan pertanyaan pada standar 3.3.1 Buku III A Borang Akreditasi Program Studi yang meliputi:

1. Integritas (etika dan moral)

2. Profesionalisme (keahlian berdasarkan ilmu)

3. Penguasaan teknologi informasi

4. Kerjasama dalam tim

5. Pengembangan diri

6. Kepemimpinan/Leadership

7. Kemampuan berbahasa asing

8. Kemampuan berkomunikasi

9. Kemampuan inovasi dan kreativitas

10. Motivasi dalam bekerja

Selain mengetahui penilaian stakeholder terhadap alumni, penelitian ini juga bertujuan mengetahui kriteria penerimaan pegawai menurut stakeholder tentang:

1. Kesesuaian Bidang studi

2. Spesialisasi (Fokus Bidang Studi)

3. Prestasi Akademik (Transkrip)

4. Soft Skill

5. Hard Skill

6. Pengalaman Kerja

7. Kemampuan Bahasa Asing

8. Penguasaan Teknologi Informasi

9. Kepribadian

\section{Metode Penelitian}

Jenis penelitian ini adalah penelitian survey. Populasi pada penelitian ini adalah seluruh pengguna lulusan Angkatan 2012-2014 yang berjumlah 130 orang. Sampel penelitian adalah pengguna lulusan antara tahun 2016-2019 (angkatan 2012-2014) yang memberikan tanggapan dengan mengisi data kuesioner melalui aplikasi google docs (google form). Penggunaan aplikasi ini untuk memudahkan dan mempercepat perolehan data. Alasan pemilihan sampel adalah: (1) alumni yang sudah pernah mengisi tracer study terkait penelusuran alumni, (2) tempat kerja alumni tertulis dengan jelas.

Langkah-langkah penelitian antara lain (1). Tahap Pra-lapangan yakni peneliti melakukan pemetaan terhadap alumni yang sudah mengisi data Tracer study penelusuran alumni sehingga didapat data tempat kerja alumni dan menyusun rancangan penelitian, (2). Tahap Pekerjaan Lapangan, dalam tahap ini peneliti memasuki dan memahami setting penelitian dalam rangka pengumpulan data. Langkah-langkahnya sebagai berikut: Melaksanakan penelusuran terhadap pengguna alumni yang memberikan respon dengan mengisi database di google form, Menyusun data lapangan sebagai bahan laporan, Evaluasi dan refleksi, (3).Tahap Analisis Data, Peneliti melakukan serangkaian proses analisis data kuantitatif berupa data kuesioner dari stakeholder sampai pada interpretasi data yang sudah diperoleh. (4).Tahap Evaluasi dan Pelaporan, Tahap ini merupakan tahap terakhir 
mengevaluasi hasil penilaian stakeholder tentang alumni. Sehingga dapat digunakan untuk perbaikan kurikulum dan pembelajaran di jurusan pendidikan kimia.

Metode analisis data yang digunakan adalah analisis statistik deskriptif. Analisis yang dimaksud merupakan teknik yang digunakan untuk memberikan gambaran lebih detail mengenai evaluasi dan penilaian pengguna lulusan. Setiap dimensi variabel akan digambarkan secara kuantitatif berdasarkan perolehan data.

\section{Hasil dan Pembahasan}

Tahap pertama yang dilakukan adalah melakukan pemetaan tempat kerja alumni dari data Tracer study penelusuran alumni angkatan tahun 2012-2014. Data tempat kerja yang diperoleh kemudian ditindaklanjuti dengan mengirimkan kuesioner yang berkaitan dengan respon stakeholder. Stakeholder mengisi kuesioner dengan membuka link berikut: https://forms.gle/E45k6F34AvaUtUxQ7.

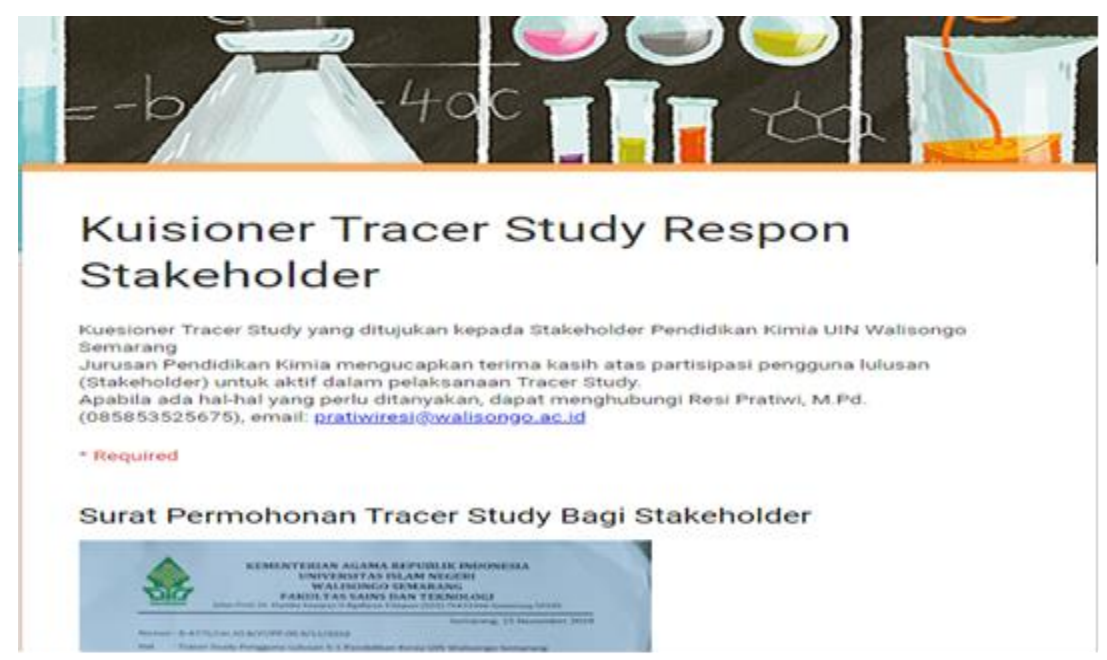

\section{Gambar 1. Tampilan google form kuesioner tracer study Jurusan Pendidikan Kimia}

Pemetaan ini dilakukan untuk mengetahui informasi secara lebih rinci terkait kebutuhan stakeholder dalam menyerap tenaga kerja. Pemetaan dan pengelolaan dilakukan agar penelusuran alumni dan informasi yang berkaitan dapat dilakukan secara terus menerus. Sehingga jurusan dapat melakukan perbaikan kurikulum secara kontinu yang disesuikan dengan kebutuhan stakeholder. Hal ini sesuai dengan pernyataan Fahriany, et al. (2014) bahwa paling tidak terdapat empat alasan mengapa keberadaan, kontribusi dan peran alumni sangat penting untuk dilacak dan didata. Pertama, keberhasilan alumni di masyarakat adalah keberhasilan program studi. Kedua, ukuran tercapai atau tidaknya visi dan misi program studi dapat dilihat pada keberhasilan alumni dalam mengembangkan profesinya di masyarakat, terutama di lembaga pendidikan. Ketiga, BAN PT Kemenristekdikti mengamanahkan perlunya dilakukan Tracer study dalam salah satu standar penilaian boring akreditasi Jurusan/Prodi adalah profil mahasiswa dan alumni. Dan 


\section{At-Taqaddum}

Vol. 12 No. 1 (2020) 55-74

keempat, keberadaan database alumni program studi merupakan sebuah keharusan untuk evaluasi program studi berbasis evaluasi diri.

Di tengah perkembangan teknologi yang serba cepat ini mahasiswa harus memiliki keterampilan hidup abad 21 yang berguna untuk beradaptasi perubahan di masyarakat dan perkembangan teknologi yang semakin cepat. Perkembangan abad ke-21 dengan munculnya revolusi industri 4.0 dan society 5.0 sebagai super smart society, serta perkembangan sains dan teknologi dalam berbagai aspek kehidupan dan kesepakatan masyarakat regional dan global berdampak pada tuntutan kompetensi lulusan. National Education Association (n.d.) telah mengidentifikasi keterampilan abad ke-21 sebagai keterampilan "The 4Cs." "The 4Cs" meliputi berpikir kritis, kreativitas, komunikasi, dan kolaborasi. The Partnership for 21st Century Skills (2008) juga mengidentifikasi keterampilan abad ke-21 yang sangat diperlukan oleh lulusan untuk berprestasi dan berkompetisi di abad ke-21. Keterampilan ini dapat meningkatkan kemampuan daya jual (marketability), kemampuan bekerja (employability), dan kesiapan menjadi warga negara (readiness for citizenship) yang baik.

The Partnership for 21st Century Learning (2015) telah mengembangkan visi belajar yang dikenal dengan nama The Framework for 21 st Century Learning. Kerangka ini menjelaskan keterampilan, pengetahuan, dan keahlian yang harus dikuasai oleh peserta didik agar berhasil dalam kerja dan kehidupan. Kerangka ini meliputi mata pelajaran utama dan tema abad ke-21, hasil belajar peserta didik abad ke-21, dan sistem pendukung (Gambar 2).

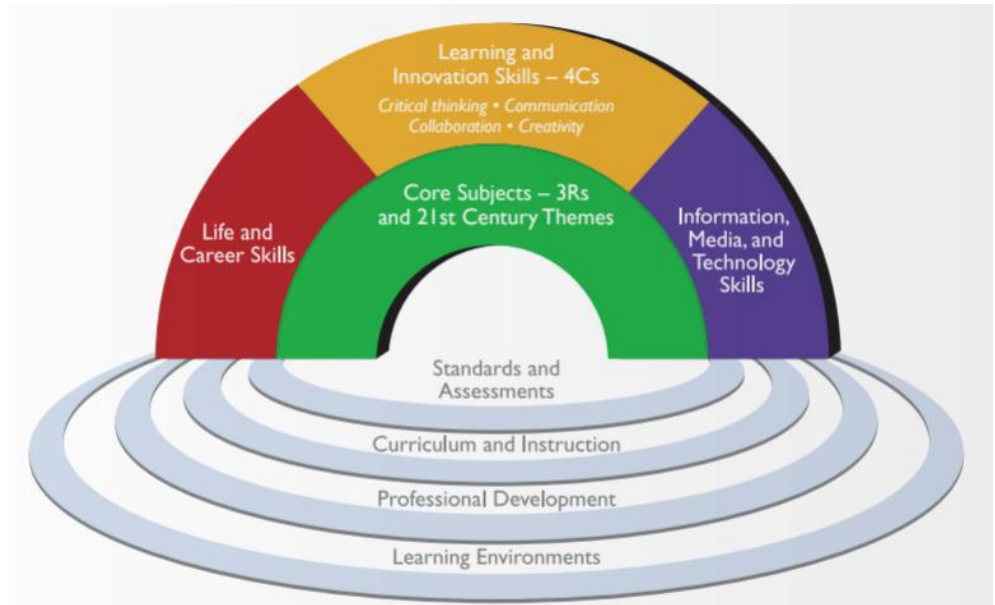

Gambar 2. Hasil belajar peserta didik abad ke-21 dan sistem pendukung

Hasil penilaian stakeholder terhadap lulusan sebagai berikut:

1. Integritas (etika dan moral)

Penilaian mengenai integritas berkaitan dengan tingkat kepentingan dan kepuasaan jurusan dan pengguna terhadap moral dan etika lulusan. Hasil survey menunjukkan bahwa $63 \%$ responden menilai integritas alumni pendidikan kimia sangat baik dan 37\% responden menilai baik. 


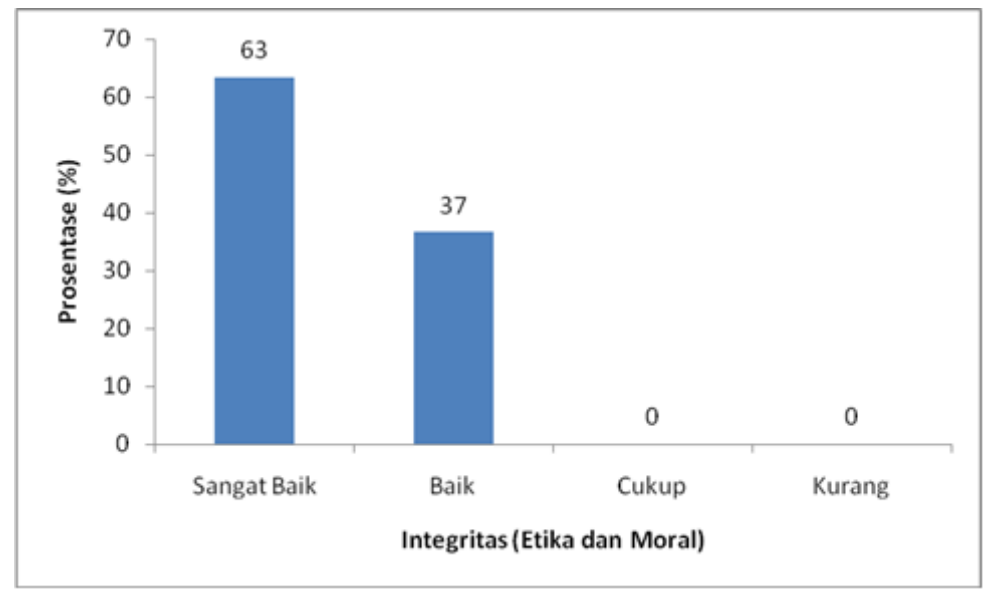

Gambar 3. Penilaian Stakeholder terhadap integritas alumni

2. Profesionalisme (keahlian berdasarkan ilmu)

Penilaian mengenai profesionalisme berkaitan dengan cara yang dilakukan untuk mengukur kompetensi alumni pendidikan kimia terhadap penguasaan materi. Penilaian ini juga digunakan untuk mengukur kompetensi alumni dalam hal pelaksanaan tugas dan fungsi dalam bekerja secara baik dan benar sesuai komitmen pada tempat kerja. Lulusan dapat dikatakan memiliki profesionalisme apabila dapat mengintegrasikan kemampuan pedagogis dan konten materi, atau memiliki kemampuan pedagogical content knowledge yang baik (Fariyani et al., 2020). Hasil survey menunjukkan bahwa 49\% responden menilai profesionalisme alumni pendidikan kimia sangat baik dan $51 \%$ responden menilai baik.

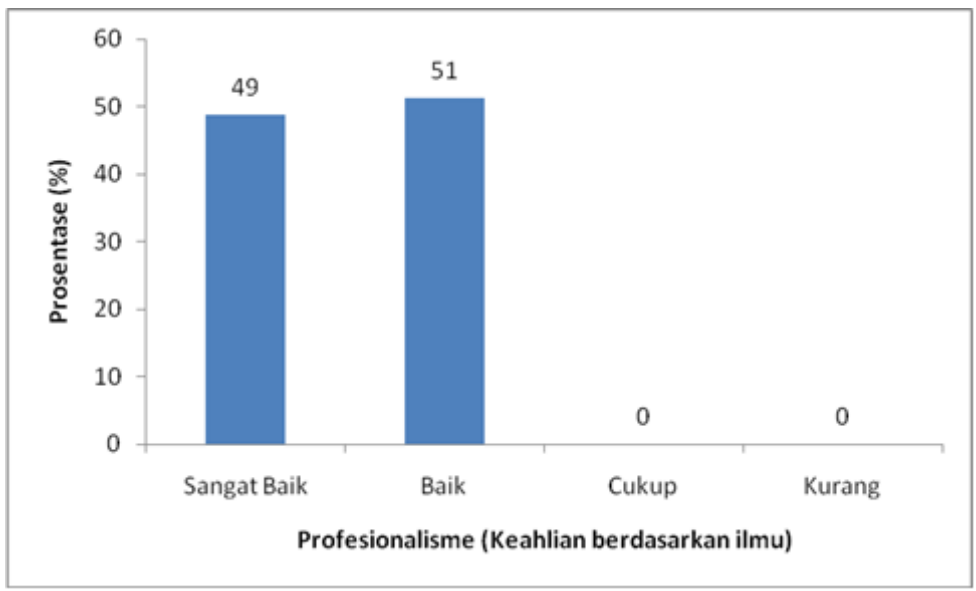

Gambar 4. Penilaian Stakeholder terhadap profesionalisme alumni

3. Penguasaan teknologi informasi

Penilaian penguasaan teknologi informasi merupakan cara digunakan untuk mengetahui kemampuan alumni terkait penggunaan teknologi. Hal ini sangat penting, karena perkembangan teknologi yang semakin pesat, sehingga penguasaan teknologi merupakan 


\section{At-Taqaddum}

Vol. 12 No. 1 (2020) 55-74

aspek dasar yang harus dimiliki alumni dalam menjalankan pekerjaan. Orang-orang yang hidup di era teknologi dan media ditandai oleh karakteristrik mengakses sejumlah informasi yang tersedia melimpah, mampu berubah cepat sesuai dengan perkembangan informasi, teknologi, dan media, dan memiliki kemampuan berkolaborasi. Keterampilan dalam hal teknologi dan informasi di perguruan tinggi perlu didukung sarana dan prasarana yang memadai. Proses perkuliahan dengan menggunakan blended learning atau e learning dapat dimasukkan dalam program kurikulum di Jurusan. Hal ini bertujuan untuk membiasakan mahasiswa dengan teknologi informasi. Hasil survey menunjukkan bahwa $37 \%$ responden menilai penguasaan teknologi alumni pendidikan kimia sangat baik, 61\% responden menilai baik dan $2 \%$ responden menilai cukup.

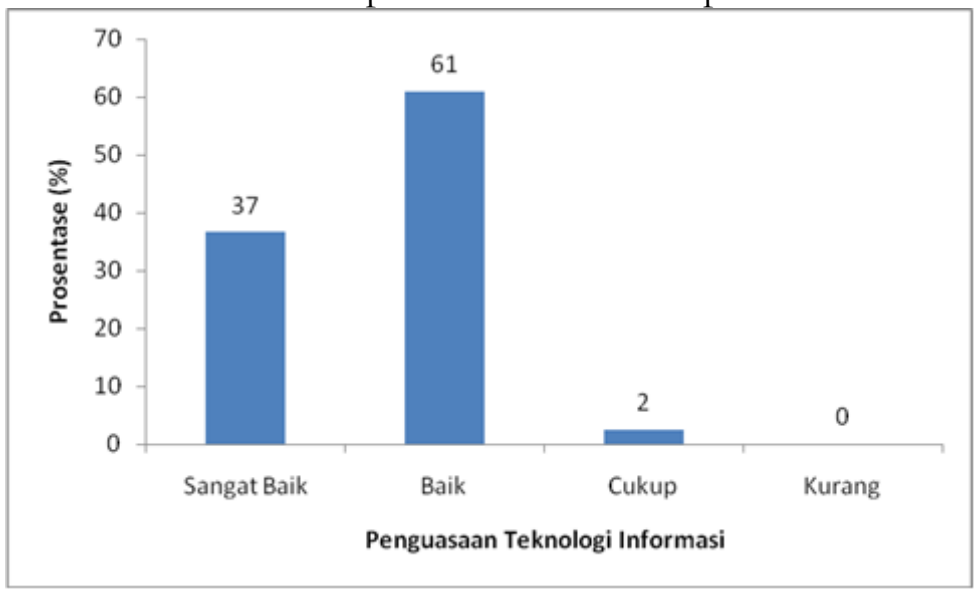

\section{Gambar 5. Penilaian Stakeholder terhadap penguasaan teknologi informasi}

4. Kerjasama dalam tim

Penilaian kerjasama dalam tim merupakan kompetensi yang harus dimiliki karena hal berkaitan dengan keberhasilan capaian pekerjaan. Alumni harus dapat bekerjasama dengan baik agar pekerjaan yang dilakukan dapat selesai sesuai dengan target yang diberikan. Kerjasama dalam tim dapat diasah pada kegiatan perkuliahan. Penggunaan berbagai metode pembelajaran dapat digunakan untuk meningkatkan kerjasama dalam tim. Hasil survey menunjukkan bahwa $37 \%$ responden menilai kerjasama tim alumni pendidikan kimia sangat baik dan 63\% responden menilai baik. 


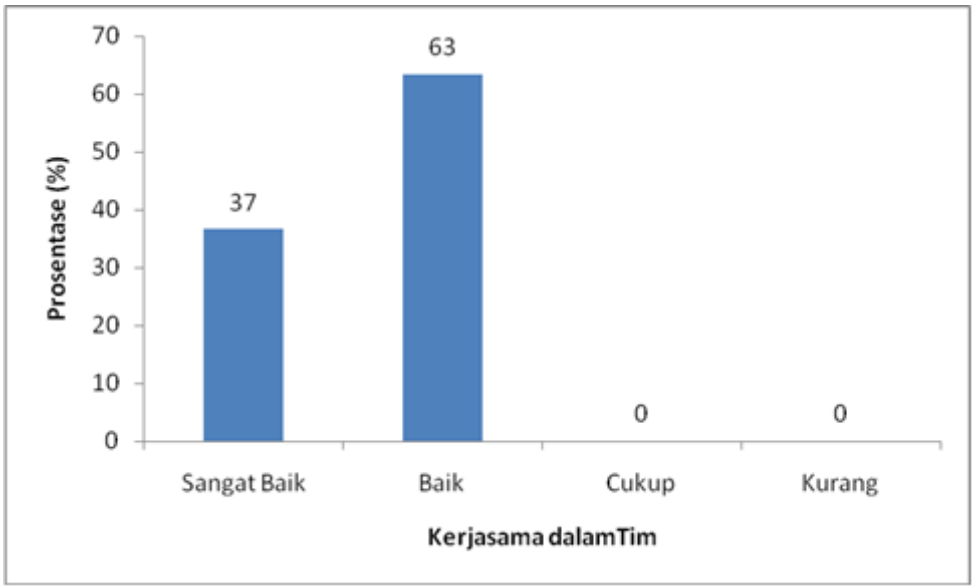

Gambar 6. Penilaian Stakeholder terhadap kerjasama dalam tim alumni

5. Pengembangan diri

Penilaian pengembangan diri alumni di tempat kerja merupakan proses peningkatan diri alumni dalam aspek sikap, pengetahuan dan keterampilan yang akan berdampak pada kualitas pekerjaan yang dilakukan alumni. Hasil survey menunjukkan bahwa 34\% responden menilai pengembangan diri alumni pendidikan kimia sangat baik, 63\% responden menilai baik dan $2 \%$ responden menilai cukup.

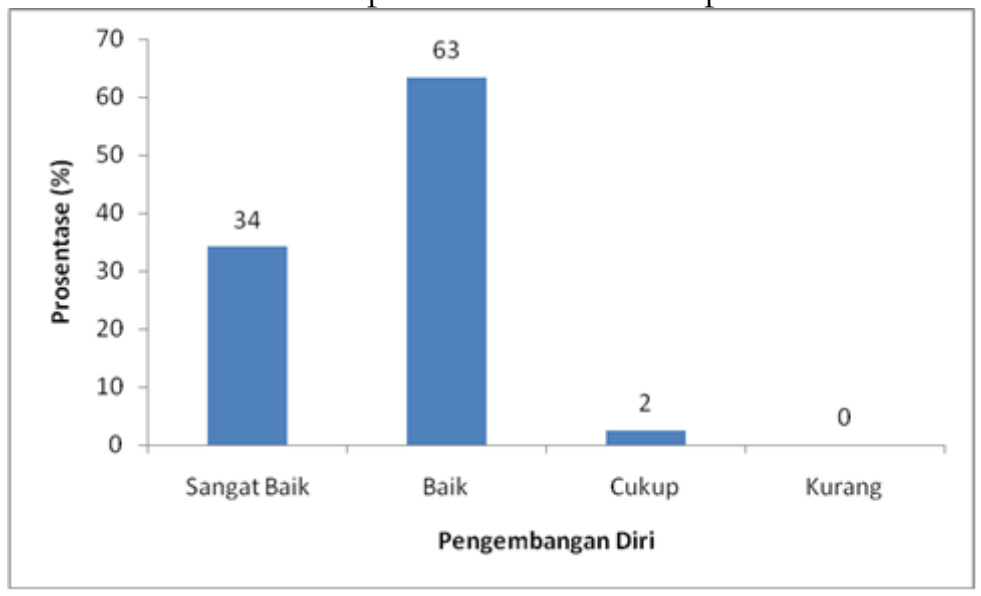

\section{Gambar 7. Penilaian Stakeholder terhadap pengembangan diri alumni}

6. Kepemimpinan/Leadership

Penilaian kepemimpinan alumni dapat digunakan untuk mengukur kemampuan alumni dalam meimpin sebuah kelompok. Kemampuan ini dapat menunjang pengembangan karir di tempat kerja. Hasil survey menunjukkan bahwa 15\% responden menilai pengembangan diri alumni pendidikan kimia sangat baik, $80 \%$ responden menilai baik dan $5 \%$ responden menilai cukup. 


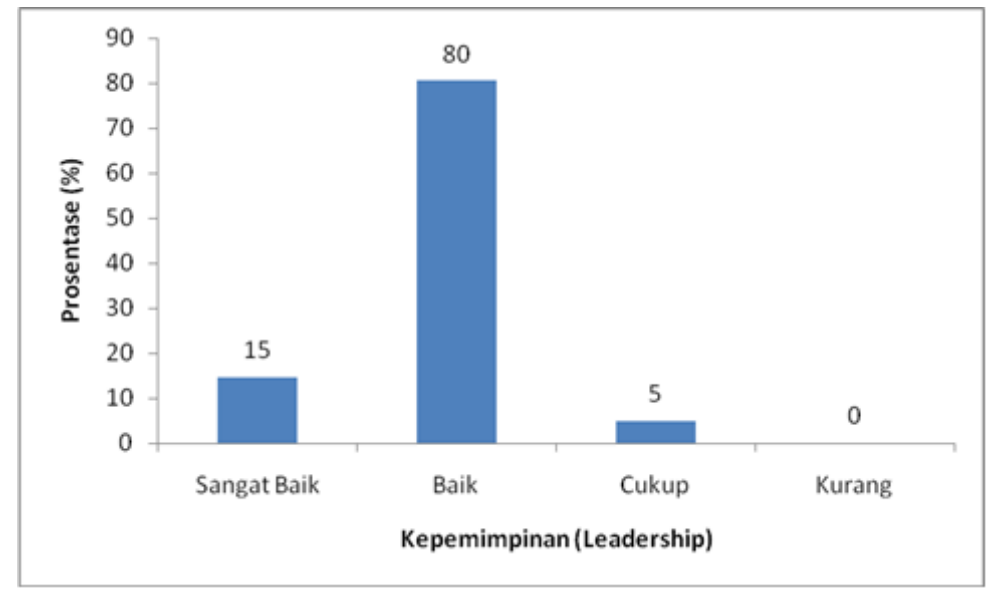

Gambar 8. Penilaian Stakeholder terhadap kepemimpinan alumni

7. Kemampuan berbahasa asing

Penilaian kemampuan berbahasa asing dalam berkomunikasi di tempat kerja merupakan modal yang berharga dalam mengembangkan karir dan menunjang seluruh aspek pengembangan diri dalam pelaksanaan pekerjaan. Bahasa asing yang sering digunakan adalah bahasa Inggris. Kemampuan berbahasa Inggris yang baik dapat memudahkan alumni dalam peningkatan karir. Hasil survey menunjukkan bahwa 10\% responden menilai kemampuan berbahasa asing alumni pendidikan kimia sangat baik, $68 \%$ responden menilai baik, $20 \%$ responden menilai cukup dan 2\% responden menilai kurang. Bakhtiar \& Latif (2017) mengungkap masukan dari pengguna lulusan yang menyarankan peningkatan kompetensi alumni dalam bidang bahasa asing khususnya bahasa inggris, kecakapan atau keterampilan pengembangan diri, serta penguasaan teknologi perlu lebih dikembangkan.

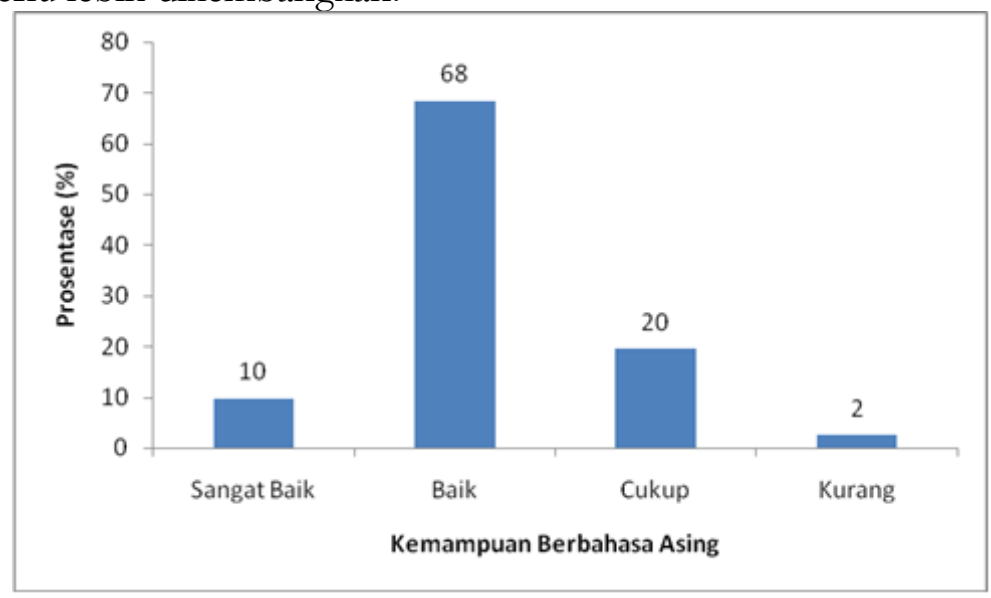

\section{Gambar 9. Penilaian Stakeholder terhadap kemampuan berbahasa asing alumni}


8. Kemampuan berkomunikasi

Penilaian kemampuan berkomunikasi alumni di tempat kerja merupakan hal yang sangat penting dalam pekerjaan. Tanpa adanya komunikasi yang baik, maka pekerjaan yang dilakukan akan terhambat. Kemampuan berkomunikasi yang baik dapat menunjang pengembangan karir dan seluruh aspek pekerjaan. Keterampilan berkomunikasi merupakan keterampilan untuk mengungkapkan pemikiran, gagasan, pengetahuan, ataupun informasi baru, baik secara tertulis maupun lisan (Ellianawati et al., 2020). Aspek ini dapat diasah dengan memberikan kesempatan pada mahasiswa untuk presentasi materi perkuliahan. Hal ini bertujuan untuk membiasakan mahasiswa dalam berkomunikasi di hadapan khalayak. Hasil survey menunjukkan bahwa 22\% responden menilai kemampuan berkomunikasi alumni pendidikan kimia sangat baik, 73\% responden menilai baik dan 5\% responden menilai cukup.

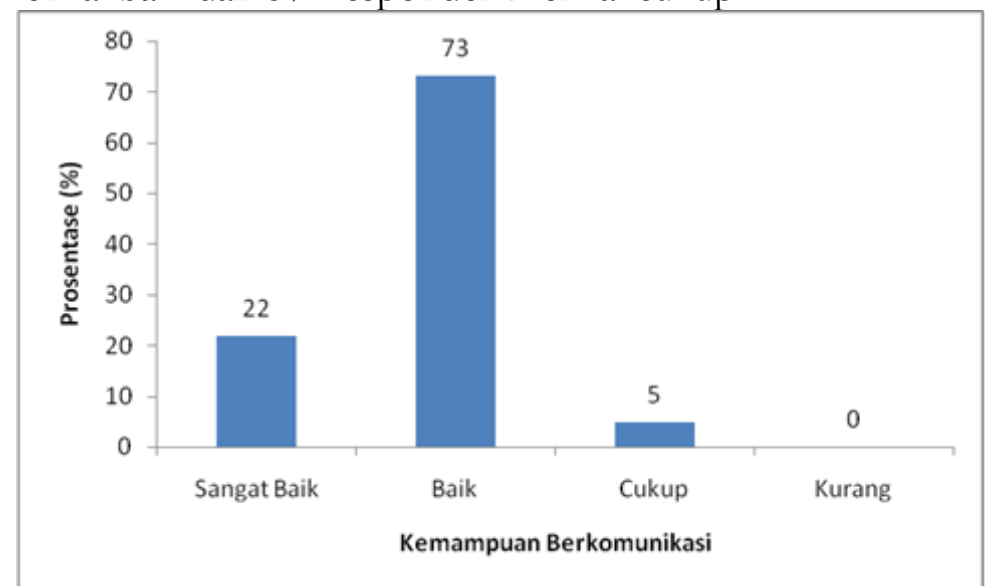

\section{Gambar 10. Penilaian Stakeholder terhadap kemampuan berkomunikasi alumni}

9. Kemampuan inovasi dan kreatifitas

Kreativitas merupakan keterampilan untuk menemukan hal baru yang belum ada sebelumnya, bersifat orisinil, mengembangkan berbagai solusi baru untuk setiap masalah, dan melibatkan kemampuan untuk menghasilkan ide-ide yang baru, bervariasi, dan unik (Leen, et al., 2014). Penilaian kemampuan inovasi dan kreatifitas alumni dapat digunakan untuk mengetahui pengembangan diri alumni di tempat kerja. Adanya kemampuan inovasi dan kreatifitas alumni yang baik akan memudahkan alumni dalam mengembangkan karir. Kemampuan inovasi dan kreatifitas mahasiswa diasah melalui penerapan beberapa mata kuliah seperti Greenpreneurship. Mahasiswa dapat berinovasi untuk membuat produk yang ramah lingkungan. Hasil survey menunjukkan bahwa $41 \%$ responden menilai kemampuan inovasi dan kreatifitas alumni pendidikan kimia sangat baik dan 59\% responden menilai baik. 


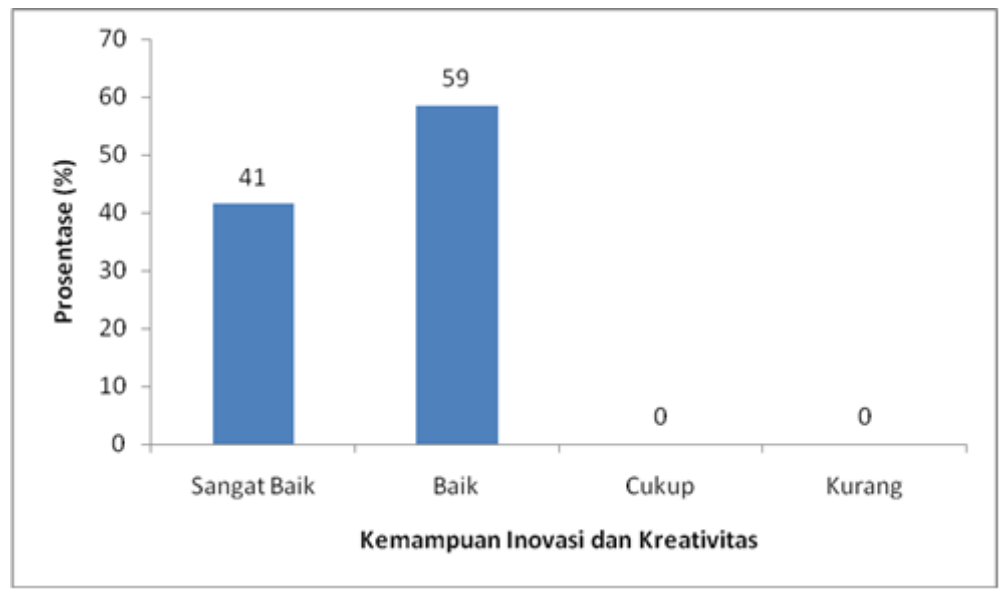

\section{Gambar 11. Penilaian Stakeholder terhadap kemampuan inovasi dan kreatifitas alumni}

10.Motivasi dalam bekerja

Motivasi merupakan dorongan atau daya penggerak. Motivasi bekerja yang baik menandakan adanya dorongan kepada seseorang untuk melakukan pekerjaan dengan sebaik-baiknya. Motivasi dalam bekerja merupakan hal yang penting untuk menunjukkan loyalitas seseorang terhadap pekerjaan yang digelutinya. Hasil survey menunjukkan bahwa $46 \%$ responden menilai Motivasi dalam bekerja alumni pendidikan kimia sangat baik dan 51\% responden menilai baik.

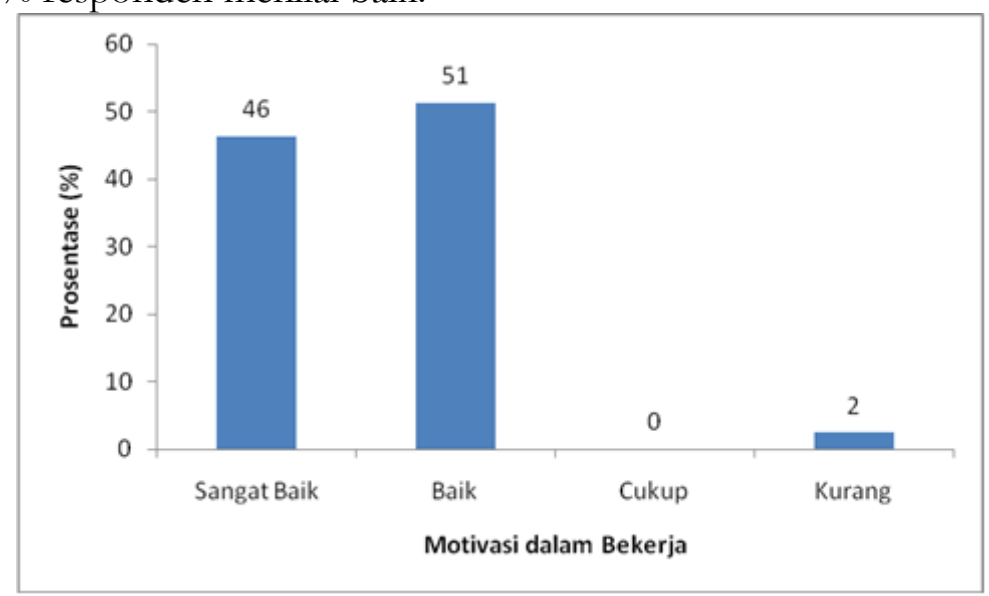

Gambar 12. Penilaian Stakeholder terhadap motivasi dalam bekerja alumni

Berdasarkan hasil rekapitulasi tersebut, rata-rata penilaian stakeholder terhadap alumni pendidikan kimia UIN Walisongo Semarang adalah baik. Hal ini didukung dengan hasil wawancara dengan kepala sekolah SMA Ma'arif Karangawen Demak yang menyatakan bahwa tingkat penguasaan materi alumni Pendidikan Kimia UIN Walisongo Semarang sudah bagus. Namun, ada responden yang menilai kurang yaitu kemampuan bahasa asing 
dan motivasi dalam bekerja. Hal ini harus menjadi perhatian jurusan pendidikan kimia, agar dapat melakukan evaluasi untuk meningkatkan kemampuan bahasa asing dan motivasi bekerja mahasiswa. Sehingga ketika mahasiswa lulus, mendapatkan bekal yang cukup dan siap untuk bekerja.Kriteria penerimaan pegawai menurut stakeholder.

1. Kesesuaian Bidang studi

Kesesuaian bidang studi dapat dikaitkan dengan relevansi pendidikan. "Relevansi pendidikan adalah tingkat keterkaitan tujuan maupun hasil keluaran program ditinjau dari ukuran ideal secara normatif yang didukung oleh ketepatan unsur masukan, proses dan keluaran" (Panduan Akreditasi, 2004). Menurut Muhson, et al. (2012), suatu lembaga pendidikan tinggi dikatakan relevan keberadaannya jika seluruhnya atau setidaknya sebagian besar lulusannya dapat dengan cepat diserap oleh lapangan kerja yang sesuai dengan bidang dan peringkat stratanya, baik di tingkat lokal, nasional maupun internasional. Hasil survey menunjukkan bahwa 56\% responden menilai kesesuian bidang studi bagi pegawai sangat penting dan $22 \%$ responden menilai penting.

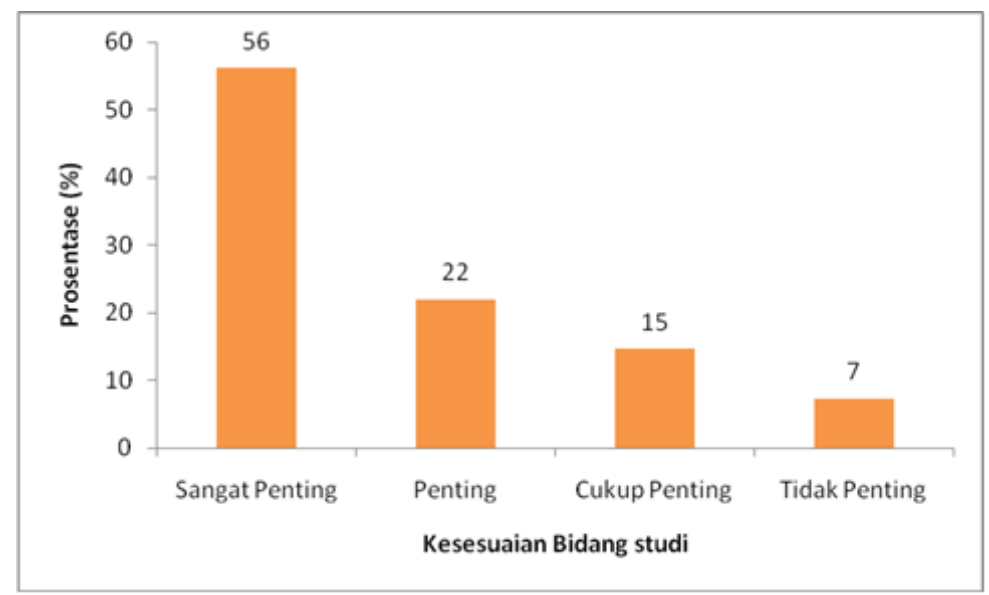

\section{Gambar 13. Kriteria Stakeholder tentang kesesuaian bidang studi pegawai}

2. $\quad$ Spesialisasi (Fokus Bidang Studi)

Spesialisasi (fokus bidang studi) merupakan keterampilan khusus yang dimiliki. Seseorang yang memiliki spesialisasi biasanya akan mudah mendapatkan pekerjaan yang sesuai. Hasil survey menunjukkan bahwa 46\% responden menilai spesialisasi (fokus bidang studi) bagi pegawai sangat penting dan 37\% responden menilai penting. 


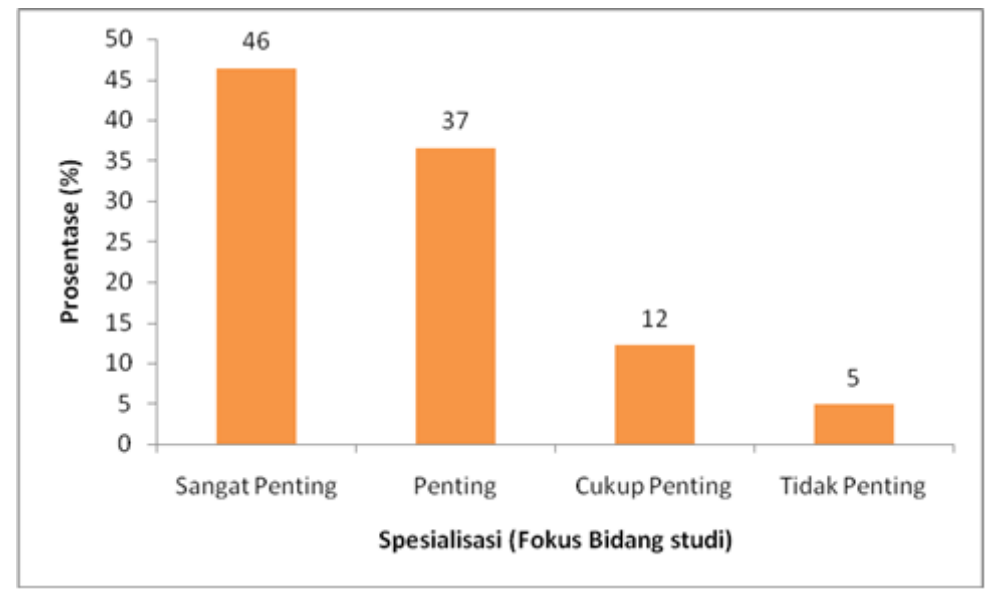

\section{Gambar 14. Kriteria Stakeholder tentang spesialisasi (fokus bidang studi) pegawai}

3. Prestasi Akademik (Transkrip)

Hasil survey menunjukkan bahwa $17 \%$ responden menilai prestasi akademik (transkrip) bagi pegawai sangat penting dan $66 \%$ responden menilai penting.

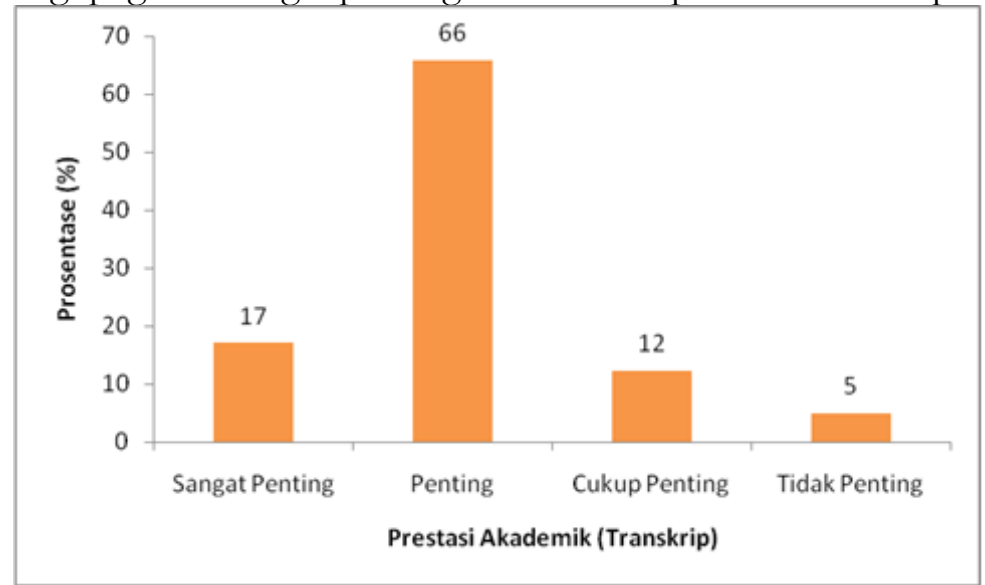

\section{Gambar 15. Kriteria Stakeholder tentang prestasi akademik (transkrip) pegawai}

4. Soft Skill

Soft Skill merupakan tingkah laku personal dan interpersonal yang dapat mengembangkan dan memaksimalkan kinerja manusia (melalui pelatihan, pengembangan kerja sama tim, inisiatif, pengambilan keputusan lainnya (Rasid, et al, 2018). Menurut (Susanto, 2012), 80\% kesuksesan manusia ditentukan oleh bagaimana cara ia membawa diri atau mengelola emosinya di tempat kerja. Hasil survey menunjukkan bahwa $51 \%$ responden menilai Soft Skill bagi pegawai sangat penting dan $49 \%$ responden menilai penting. 


\section{Hard Skill}

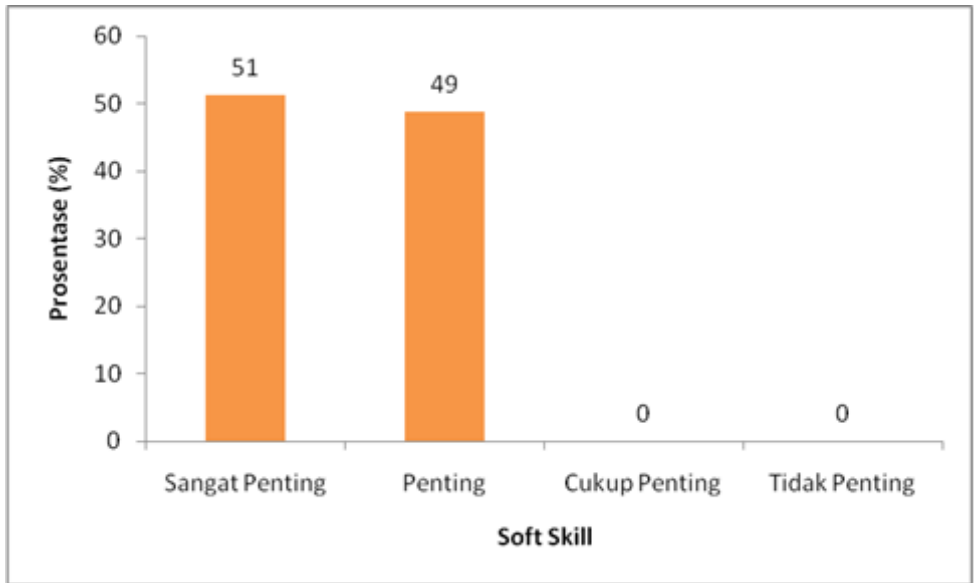

\section{Gambar 16. Kriteria Stakeholder tentang Soft Skill pegawai}

Menurut Rasid, et al. (2018), dalam dunia kerja, Hard Skill dan Soft Skill sangat berpengaruh terhadap kinerja dan prestasi karyawan. Keduanya sangat penting dan saling melengkapi satu sama lain. Ada anggapan yang menyatakan bahwa Hard Skill lebih penting daripada Soft Skill. Itu tidak serta merta salah, mengingat dengan adanya Hard Skill bisa diketahui apa yang harus dikerjakan dari awal sampai dengan selesai sesuai dengan bidang yang kita geluti. Hasil survey menunjukkan bahwa 37\% responden menilai Hard Skill bagi pegawai sangat penting dan 63\% responden menilai penting.

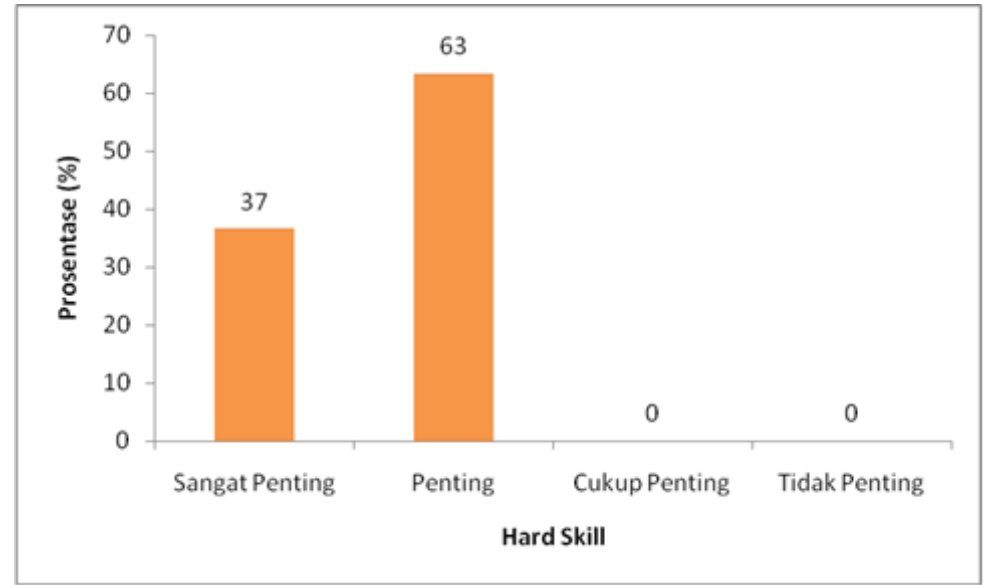

Gambar 17. Kriteria Stakeholder tentang Hard Skill pegawai

6. Pengalaman Kerja

Pengalaman dapat memunculkan potensi seseorang. Potensi yang penuh akan muncul secara bertahap seiring berjalannya waktu sebagai tanggapan terhadap bermacammacam pengalaman. Orang yang berpengalaman dalam bekerja biasanya memiliki kemampuan kerja yang lebih baik dari orang yang baru saja memasuki dunia kerja. Orang tersebut telah belajar dari kegiatan-kegiatan dan permasalahan yang timbul 


\section{At-Taqaddum}

Vol. 12 No. 1 (2020) 55-74

dalam kerjanya. Dengan adanya pengalaman kerja maka telah terjadi proses penambahan ilmu pengetahuan dan keterampilan serta sikap pada diri seseorang, sehingga dapat menunjang dalam mengembangkan diri dengan perubahan yang ada. Hasil survey menunjukkan bahwa $41 \%$ responden menilai pengalaman kerja bagi pegawai penting dan 39\% responden menilai cukup penting.

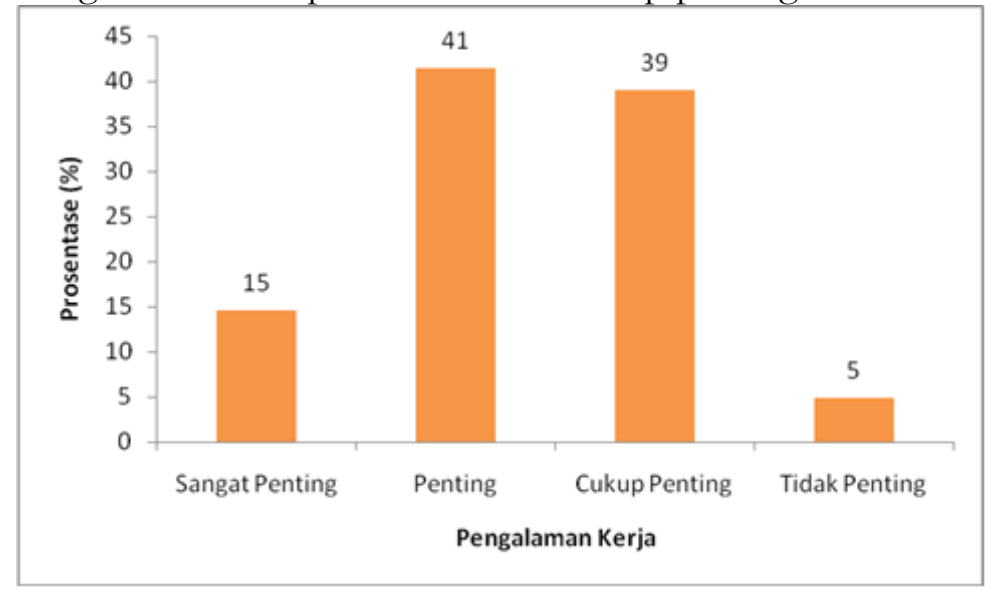

Gambar 18. Kriteria Stakeholder tentang pengalaman kerja pegawai

7. Kemampuan Bahasa Asing

Di era globalisasi sekarang ini, penggunaan bahasa asing juga turut berkembang. Bahasa Inggris merupakan bahasa yang paling banyak digunakan. Kemampuan berbahasa Inggris menjadi salah satu faktor penting dalam dunia kerja. Hasil survey menunjukkan bahwa $27 \%$ responden menilai kemampuan berbahasa asing bagi pegawai sangat penting dan $59 \%$ responden menilai penting.

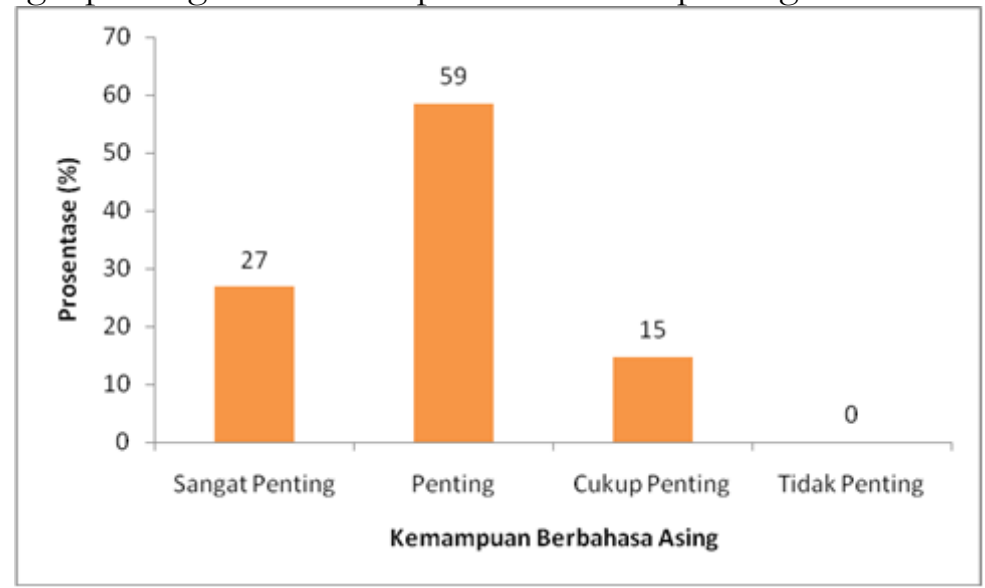

Gambar 19. Kriteria Stakeholder tentang kemampuan berbahasa asing pegawai

8. Penguasaan Teknologi Informasi

Penguasaan teknologi informasi saat ini menjadi factor yang penting dalam dunia kerja. 
Hasil kinerja yang efisien dan efektif dapat diwujudkan apabila organisasi mampu berinteraksi dengan suatu teknologi informasi yang ada dan memanfaatkan teknologi informasi tersebut untuk membantu mencapai tujuan mereka. Hasil survey menunjukkan bahwa 39\% responden menilai penguasaan teknologi informasi bagi pegawai sangat penting dan 59\% responden menilai penting.

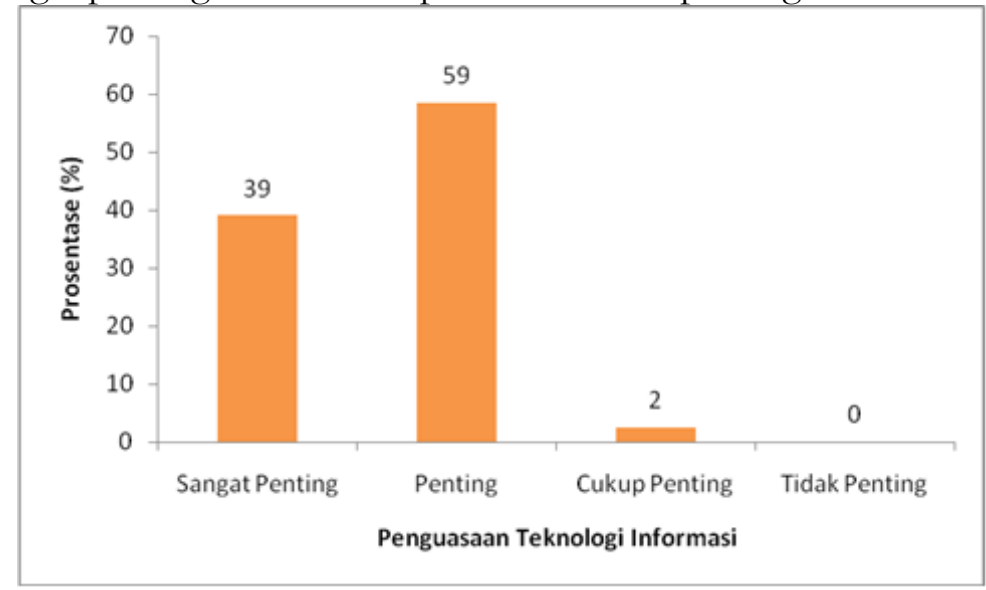

\section{Gambar 20. Kriteria Stakeholder tentang penguasaan teknologi informasi pegawai}

9. Kepribadian

Penelitian yang dilakukan oleh Hogan dalam Widhiastuti (2010) menghubungkan antara kepribadian dengan kinerja, yang hasilnya adalah bahwa secara garis besar sangat berarti. Rangkaian yang lebih tinggi tingkatannya menggambarkan kepribadian secara unik sebagai instrumen yang terstandar, yang memprediksi hubungan dengan pendekatan kinerja. Hasil survey menunjukkan bahwa 46\% responden menilai kepribadian bagi pegawai sangat penting dan 54\% responden menilai penting.

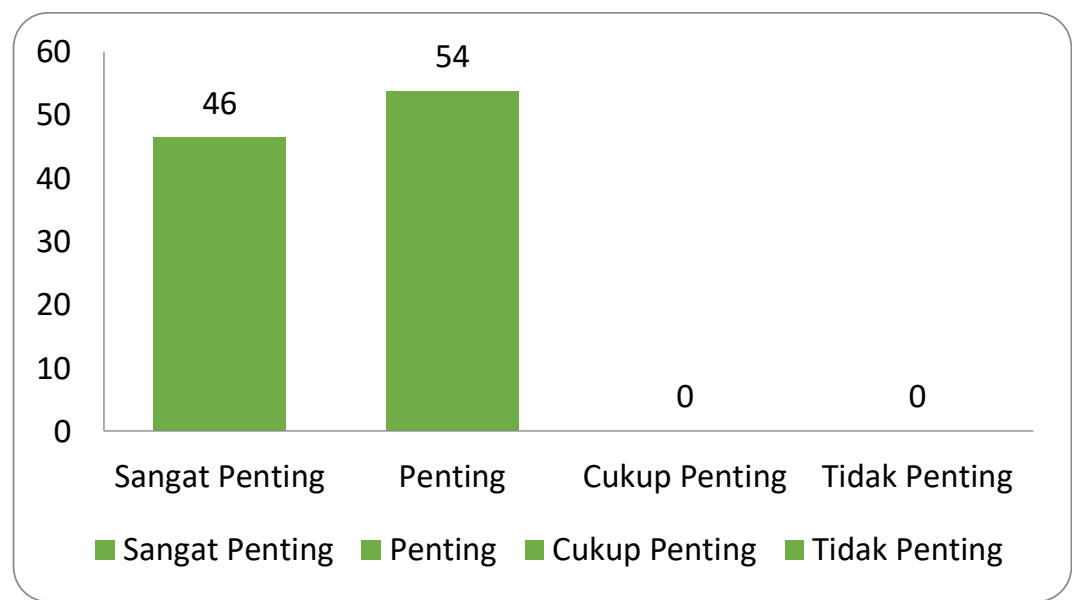

Gambar 21. Kriteria Stakeholder tentang kepribadian pegawai

Sebagai bahan masukan untuk perbaikan dan pengembangan kurikulum di jurusan 
pendidikan kimia, peneliti juga meminta saran dari stakeholder terkait dengan proses pembelajaran maupun kurikulum yang dipersiapkan. Berikut rangkuman saran dari stakeholder:

1. Menjadi kampus yang slalu mengedepankan nilai agama tetapi juga tidak ketinggalan nilai akademiknya

2. Semakin terdepan dalam mencetak tenaga pendidik yang profesional

3. Menambah kemampuan lulusan dalam bidang teknologi informasi dan komunikasi

4. Lebih inovatif terhadap perkembangan dan perubahan kurikulum

5. Memiliki sertifikat pendamping wisuda untuk skill tertentu

6. Meningkatkan kerja sama dengan badan pengelola pendidikan di Indonesia untuk bisa menampung lulusan sesuai kualifikasinya.

7. Membekali mahasiswa dengan kemampuan Soft Skill juga peningkatan kemampuan bahasa asing, misalnya melalui analisis jurnal internasional.

Dari hasil penelitian ini, Jurusan Pendidikan Kimia dapat melakukan evaluasi terhadap lulusan di tempat kerja, sebagai bahan untuk perbaikan kurikulum. Hal sesuai dengan penelitian Suyati, et al., (2012) yang menyatakan manfaat studi penelusuran adalah sebagai bahan untuk mengevaluasi diri. Hasil penelitian ini juga sangat bermanfaat sebagai masukan Jurusan Kimia. Sebagaimana disebutkan oleh Kementerian Pendidikan dan Kebudayaan (2012), bahwa Tracer study bermanfaat untuk mengetahui: (1) Outcome pendidikan dalam bentuk transisi dari dunia pendidikan tinggi ke dunia kerja (termasuk masa tunggu kerja dan proses pencarian kerja pertama), situasi kerja terakhir, dan aplikasi kompetensi di dunia kerja, (2) Output pendidikan yaitu penilaian diri terhadap penguasaan dan pemerolehan kompetensi, dan (3) Proses pendidikan berupa evaluasi proses pembelajaran dan kontribusi pendidikan tinggi terhadap pemerolehan kompetensi Input pendidikan berupa penggalian lebih lanjut terhadap informasi sosiobiografis lulusan.

\section{Kesimpulan}

Dari penelitian ini diperoleh kesimpulan bahwa menurut stakeholder penilaian lulusan aspek integritas (moral dan etika) kategori sangat baik sebesar 63\%, aspek profesionalisme kategori baik sebesar 51\%, aspek penguasaan teknologi informasi kategori baik sebesar $61 \%$, aspek kerjasama dalam tim kategori baik sebesar 63\%, aspek pengembangan diri kategori baik sebesar 63\%, aspek kepemimpinan kategori baik sebesar 80\%, aspek kemampuan berbahasa asing kategori baik sebesar 68\%, aspek kemampuan berkomunikasi kategori baik sebesar 73\%, aspek kemampuan inovasi dan kreativitas kategori baik sebesar $59 \%$ dan aspek motivasi dalam bekerja kategori baik sebesar 51\%. Untuk kriteria penerimaan pegawai menurut stakeholder yaitu aspek kesesuaian bidang studi kategori sangat penting sebesar $56 \%$, aspek spesialisasi (fokus bidang studi) kategori sangat penting sebesar $46 \%$, aspek prestasi akademik (transkrip) kategori penting sebesar $66 \%$, aspek Soft Skill kategori sangat penting sebesar 51\%, aspek Hard Skill kategori penting sebesar 63\%, aspek pengalaman kerja kategori penting sebesar $41 \%$, aspek kemampuan berbahasa asing kategori penting sebesar 59\%, aspek penguasaan teknologi informasi kategori penting 59\% 
dan aspek kepribadian kategori penting sebesar 54\%. Dari hasil yang diperoleh juga menyimpulkan bahwa evaluasi dari berbagai bidang perlu dilakukan untuk meningkatkan dan menjaga kualitas pendidikan sehingga visi dan misi Jurusan Pendidikan Kimia dapat terwujud.

\section{References}

Bakhtiar, M. I., \& Latif, S. (2017). Tracer study Alumni: Upaya Pengembangan Prodi Bimbingan Konseling Universitas Negeri Makassar. Jurnal Kajian Bimbingan Dan Konseling, 2(1), 32-40. Retrieved from http://journal2.um.ac.id/index.php/jkbk

Ellianawati, E., Mufiatunnikmah, S., Setyaningsih, N. E., \& Subali, B. (2020). Asesmen Multi Representasi Berbasis Keterampilan Abad Ke-21 pada Materi Gerak Lurus. Physics Education Research Journal, 2(1), 19-33. https://doi.org/10.21580/perj.2020.2.1.5038

Fahriany, Musfah, J., \& Albantani, A. M. (2014). Profil sosial intelektual alumni program magister FITK UIN Syarif Hidayatullah Jakarta. Jakarta.

Fariyani, Q., Mubarok, F. K., Masfu'ah, S., \& Syukur, F. (2020). Pedagogical Content Knowledge of Pre-service Physics Teachers. Jurnal Ilmiah Pendidikan Fisika Al-BiRuNi, 9(1), 99-107. https://doi.org/10.24042/jipfalbiruni.v9i1.3409

Kemendikbud. 2012. Buku Panduan Sistem Pusat Karir Edisi II. Jakarta: Direktorat Jenderal Pendidikan Tinggi, Kementerian Pendidikan dan Kebudayaan.

Khair, M., Astuti, I. F., \& Khairina, D. M. (2016). Alumni Tracer System berbasis web (study kasus Fakultas Matematika dan ilmu pengetahuan Alam). In Prosiding Seminar Sains dan Teknologi FMIPA Unmul (pp. 471-475). Samarinda: FMIPA Universitas Mulawarman.

Leen, C.C., Hong, K.F.F.H., dan Ying, T.W. 2014. Creative and Critical Thinking in Singapore Schools. Singapore: Nanyang Technological University.

Muhson, A., Wahyuni, D., Supriyanto \& Mulyani, E. 2012. Analisis Relevansi Lulusan Perguruan Tinggi dengan Dunia Kerja. Jurnal Economia, 8(1): 42 - 52.

National Education Association. (n.d.). Preparing 21st Century Students for a Global Society: An Educator's Guide to the "Four Cs." Diakses 17 Januari 2020 dari http://www.nea.org/assets/docs/AGuide-to-Four-Cs.pdf.

Nugroho, A. (2018). Aplikasi OLAP Profil Mahasiswa dan Lulusan. Jurnal SIMETRIS, 9(1), 533540.

Pannogan, O. C., \& Ocampo, D. P. (2016). Tracer study of bachelor of arts graduates major in English. International Journal of Advanced Research in Management and Social Sciences, 5(1), 281-297.

Peraturan Menteri Pendidikan dan Kebudayaan Republik Indonesia Nomor 20 Tahun 2020 Tentang Akreditasi Program Studi dan Perguruan Tinggi. 


\section{At-Taqaddum}

Vol. 12 No. 1 (2020) 55-74

Rasid, Z., Tewal, B., \& Kojo, C. 2018. Pengaruh Hard Skill dan Soft Skill terhadap Kinerja Karyawan Perum DAMRI Manado. Jurnal EMBA, 6(2): 1008-1017.

Schomburg, H. 2003. Handbook for graduate tracer studies. Kassel: Centre for Research on Higher education and Work.

Suyati, T, Rakhmawati D, dan Maulia, D. 2012. Studi Penelusuran Terhadap Alumni Jurusan PBB FIP IKIP PGRI Semarang (Dalam Rangka Pengembangan Kurikulum). http://ejurnal.ikippgrismg.ac.id/index.php/JP3B/article/download/272/240 diakses pada tanggal 17 Januari 2020.

The Partnership for 21st Century Skills, 2008, 21st Century Skills, Education dan Competitiveness: A Resource and Policy Guide. Diakses 17 Januari 2020 dari http://www.p21.org/storage/docume.

Toba, H., Wijaya, E. A., Wijanto, M. C., \& Karnalim, O. (2017). Enhanced unsupervised person name disambiguation to support alumni tracer study. Global Journal of Engineering Education, 19(1), 42-48.

Undang-Undang Republik Indonesia Nomor 12 Tahun 2012 Tentang Perguruan Tinggi.

Wibisono, A., Ulama, B. S. S., \& Asmoro, W. A. 2012. Tracer study At Institut Teknologi Sepuluh Nopember (ITS), Promoting Localization and Multiple Touch Points To Capture Alumni. In International Conference on Experience with Link and Match in Higher Education: Result of tracer studies world wide (pp. 1-9). Denpasar.

Widhiastuti, H. 2010. Analisis Kepribadian dan Kinerja Perilaku Account Officer Jasa Keuangan. Jurnal Dinamika Sosial Budaya, 12(1): 1-24. 
At-Taqaddum

Vol. 11 No. 2 (2019) Pg. 142-151 